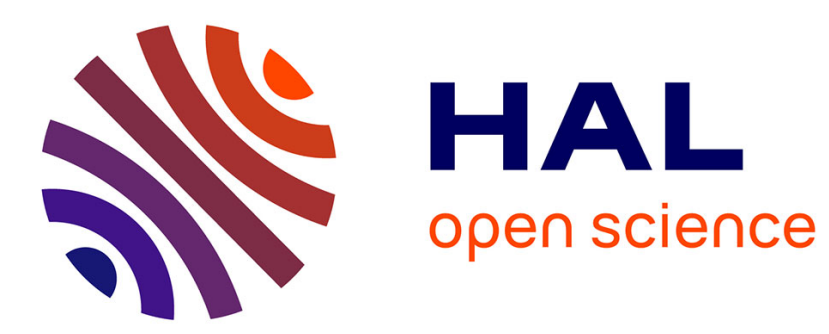

\title{
Orogenic plateau edges and the coexistence of HP and HT metamorphic rocks
}

\author{
Christian Teyssier, Donna L. Whitney, Patrice Rey, Francoise Roger
}

\section{To cite this version:}

Christian Teyssier, Donna L. Whitney, Patrice Rey, Francoise Roger. Orogenic plateau edges and the coexistence of HP and HT metamorphic rocks. 22nd EGU General Assembly 2020, May 2020, Vienne, Austria. 10.5194/egusphere-egu2020-6798 . hal-02983382

\section{HAL Id: hal-02983382 \\ https://hal.science/hal-02983382}

Submitted on 11 Dec 2020

HAL is a multi-disciplinary open access archive for the deposit and dissemination of scientific research documents, whether they are published or not. The documents may come from teaching and research institutions in France or abroad, or from public or private research centers.
L'archive ouverte pluridisciplinaire $\mathbf{H A L}$, est destinée au dépôt et à la diffusion de documents scientifiques de niveau recherche, publiés ou non, émanant des établissements d'enseignement et de recherche français ou étrangers, des laboratoires publics ou privés. 
EGU2020-6798

https://doi.org/10.5194/egusphere-egu2020-6798

EGU General Assembly 2020

(c) Author(s) 2020. This work is distributed under

the Creative Commons Attribution 4.0 License.

\title{
Orogenic plateau margin and the coexistence of HP and HT metamorphic rocks
}

\author{
Christian Teyssier ${ }^{1}$, Donna L Whitney ${ }^{1}$, Patrice F Rey ${ }^{2}$, and Françoise Roger ${ }^{3}$ \\ ${ }^{1}$ Earth and Environmental Sciences, University of Minnesota, Minneapolis, United States of America (teyssier@umn.edu) \\ ${ }^{2}$ School of Geosciences, The University of Sydney, Australia \\ ${ }^{3}$ Laboratoire Géosciences Montpellier, Université Montpellier, France
}

Mature orogenic plateaux grow in response to the lateral redistribution of plateau material, driven by gravitational potential energy, from the thick plateau crust toward the thinner foreland crust. Folding and thrusting in the shallow crust as well as flow of weak deep crust toward the foreland result in plateau growth. The balance between plateau growth processes, including gravitational collapse of the orogenic crust, and the resistance to plateau propagation controls the position of plateau margins. Toward the end of orogenic plateau development, plateau margins are the loci of steep topographic gradients, where erosional processes can be aggressive. The margins also represent the transition between thick crust and thin/weak lithosphere beneath the plateau, and thinner crust and strong/thick lithosphere below the foreland.

The juxtaposition of thick and thin lithosphere favors strain localization along plateau margins, where thick lithosphere may partially subduct, or where strike-slip systems, such as the Altyn Tagh region of northern Tibet, develop. In either case, it is likely that the deep, flowing, partially molten crust will sample and entrain high-P (HP) metamorphic rocks such as granulite and eclogite. In the case of lithospheric strike-slip systems, crustal thickening in transpressional domains may lead to HP metamorphism, and crustal thinning in transtensional domains may lead to rapid exhumation of the deep crust, particularly where pull-apart structures in the shallow-crust allow the upward flow and emplacement of migmatite domes. For example, the Montagne Noire dome (French Massif Central) formed at the southern margin of the Variscan orogen in the late Carboniferous (315-295 Ma). This dome is filled with Variscan migmatite containing eclogite fragments that were sampled near Moho depths and entrained in the flowing partially molten crust; eclogitization and early crystallization of melt were coeval. In this example, the redistribution of mass and heat across the plateau margin, including the exhumation of near-Moho rocks, stabilized the crust and marked the end of orogeny. 